\title{
Sandy bottom macroinvertebrates in two moderately polluted stations of the River Treia (Central Italy) : structural and functional organization
}

\author{
M. Bazzanti
}

Keywords : Sandy bottom, macroinvertebrates, community structure, functional feeding groups, moderate pollution, river.

A study on sandy bottom macroinvertebrates in two moderately polluted stations of the River Treia (Central Italy) was carried out in order to analyze their structural and functional feeding organization. A total of 60 taxa were collected during the study. Oligochaeta, Gammaridae, Diptera-Chironomidae and Ephemeroptera constituted the bulk of the total fauna. Most of the taxa were typical of sandy bottom habitats and moderate current flow. Collectors and shredders were the dominant feeding groups in both stations. Predators were strongly and positively correlated with the abundances of collectors and shredders (potential prey). Moreover, the direct relationships found between taxonomic and trophic diversities or between taxonomic and trophic evenness suggest a relatively good partitioning of food resources among the taxa. The most common organisms found in both stations were typical of mesosaprobic environments, indicating that the macrofauna of fine sediments seems to be suitable for detecting moderate organic pollution in rivers.

Macroinvertébrés des substrats sableux de deux statjons modérément poltuées de la rivière Treia (Italie centrale) : organisation structurale et fonctionnelle

Mots clés : Sédiments sableux, macroinvertébrés, structure de communauté, groupes fonctionnels, pollution modérée, rivière.

La structure de la communauté et l'organisation fonctionnelle alimentaire des macroinvertébrés des substrats sableux ont èté étudiés dans deux stations modérément polluées de la rivière Treia (Italie centrale). 60 taxons ont été récoltés. Oligochaeta, Gammaridae, Diptera-Chironomidae et Ephemeroptera constituent la plus grande partie de la faune. Presque tous les taxons sont typiques des milieux sableux à vitesse de courant modérée. Collecteurs et broyeurs sont les groupes fonctionnels alimentaires dominants. L'abondance des prédateurs est bien corrélée avec celle des collecteurs et des broyeurs (proies potentielles). En outre, les relations directes entre la diversité taxonomique et la diversité trophique ou l'équitabilité taxonomique et l'équitabilité trophique montrent une bonne répartition des ressources alimentaires entre les différents taxons. Les organismes des deux stations de la rivière sont pour la plupart typiques des milieux mésosaprobes et indiquent que la macrofaune des substrats fins semble bien refléter l'état des rivières, lorsque la pollution organique est modérée.

\section{Introduction}

The ecological effects of organic pollution on lotic macroinvertebrates have been long recognized (Hynes 1960, Klein 1962, Hawkes 1979, Hellawell 1978,1986 , and others). Whereas heavy organic pollution generally produces drastic effects on the benthic fauna, mild or moderate organic enrichment is less recognizable (Hynes 1960, 1970, Cook 1976), and can constitute an insidious form of pollution

1. Dipartimento di Biologia Animale e dell'Uomo, Università "La Sapienza ", viale dell'Università 32,00185 Roma, lalia.
(Dolédec 1987) that is often underestimated because of the greater recovery efficiency of lotic waters when compared with lentic ecosystems.

It is generally accepted that riffle communities are more sensitive to organic pollution than communities inhabiting slower flowing riverine zones (cf. Hawkes 1979, Goldman \& Horne 1983, Whatton \& Hawkes 1984), and in fundamental and applied studies, biological communities in soft substrate and low current velocity have often been neglected, even if good results have been recently obtained (Cook 1976, Whitman \& Clark 1984, Rae 1985, McCulloch 1986, Roeding \& Smock 1989). 
On the other hand, deoxygenation, which is the major factor involved in organic pollution, affects the organisms living both in hard and soft substrata, according to the different oxygen demand and pollution tolerance of the various species inhabiting them (Klein 1962). Consequently, macroinvertebrates of soft bottom habitats with a low current velocity may be efficient to detect complementary information to assess a moderate state of organic pollution of rivers.

In 1978 , a research program promoted by the ACEA ( Azienda Comunale Energia e Ambiente ") was carried out in order to assess the water quality in two sites of the River Treia, Central Italy (Ferrero, unpublished report). In the present paper, data on the macroinvertebrate communities of these two sampling sites with comparable characteristics (sandy substrate and low current flow prevailing) are reported with the following aims :

a) to contribute to the knowledge of the structural and functional parameters of the macroinvertebrate community of soft substrates in moderately poliuted waters, considering that relatively little data have been published about this type of habitat;

b) to confirm the value as a bioindicator of the sandy bottom fauna in relation to the chemical diagnosis of the surface water.

\section{Site description and methods}

The River Treia (drainage basin area : $497 \mathrm{~km}^{2}$ ) is located North of Rome in the volcanic district of the Sabatini Mountains. It originates from several springs and after about $35 \mathrm{~km}$ flows into the River Tiber (fig. 1). The Treia receives domestic sewage from a number of towns located in its drainage basin and nutrients from agricultural and pasture activities in surrounding areas. Detailed descriptions of geological and botanical characteristics of the zone can be found in Alvarez (1972) and Blasi et al. (1981), respectively. Since 1988, most of the drainage basin area of the River Treia has been part of a suburban park located between the cities of Viterbo and Rome.

Macroinvertebrates from the stations $\mathrm{A}$ and $\mathrm{B}$ (about $180 \mathrm{~m}$ a.s.l. and $40 \mathrm{~m}$ a.s.l., respectively) were collected six times from January to October 1978. Samples were restricted to a sandy bottom area with a relatively low current speed (generally $<30$ $\mathrm{cm} / \mathrm{s}$ ). The water quality was rather similar in the two stations (fig. 2) and indicated a moderate organic pollution revealed by values of $N$ and $P$ compounds, exceeding those of unpolluted waters (cf. Tümpling 1969, Nisbet \& Verneaux 1970, Schmitz et al. 1979, Leclercq \& Maquet 1987). The oxygen content was high and BOD values were low during the year, indicating a good self-purification of the river. Benthic fauna was sampled by means of a drag net (Cummins 1962, Hellawell 1978) pushed through the stream bottom at a fixed depth of about $10 \mathrm{~cm}$ and dragged upstream for a length of $0.5 \mathrm{~m}$ in order to completely remove $0.15 \mathrm{~m}^{2}$ of sediment. The net had a frame of $30 \times 20 \mathrm{~cm}$ and a $0.28 \mathrm{~mm}$ mesh opening. At each station, two samples were collected across the river bed at about $0.3 \mathrm{~m}$ depth. Material was preserved in the laboratory at low temperature and sorted out within two days. Macroinvertebrates were picked live by hand, stored in $70^{\circ}$ alcohol and identified at the lowest possible taxonomic level. The numbers of organisms from the two samples per station were averaged and the results expressed as number $/ \mathrm{m}^{2}$. Organisms were assigned to the functional feeding categories according to Merritt \& Cummins (1984) and Cummins \& Wilzbach (1985). Diversity and evenness indices (Pielou 1969) were performed on both taxonomic and feeding group numbers. Similarity was calculated by means of PSc index (Whittaker \& Fairbanks 1958) and the results reported in dendrograms following UMPGA (unweighted pair group using mathematical averages) clustering method (Sneath \& Sokal 1973). According to Williams et al. (1969), a matrix of correlation coefficients ( $r$ ) using all samples from the two sites (considering seasonal samples as replicates) was calculated to examine relationships among structural and functional parameters of the community. Significance in some community characteristics between the two stations was calculated by the non-parametric Wilcoxon matched-pair signedranks test (Eason et al. 1980). Finally, Principal Component Analysis (PCA), widely used in aquatic ecology, was applied to $\log (x+1)$ transformed densities of taxa and functional feeding groups.

\section{Results}

\subsection{Composition, community structure and func- tional organization}

A total of 60 taxa, mostly belonging to DipteraChironomidae (24), Oligochaeta (15) and Ephemeroptera 


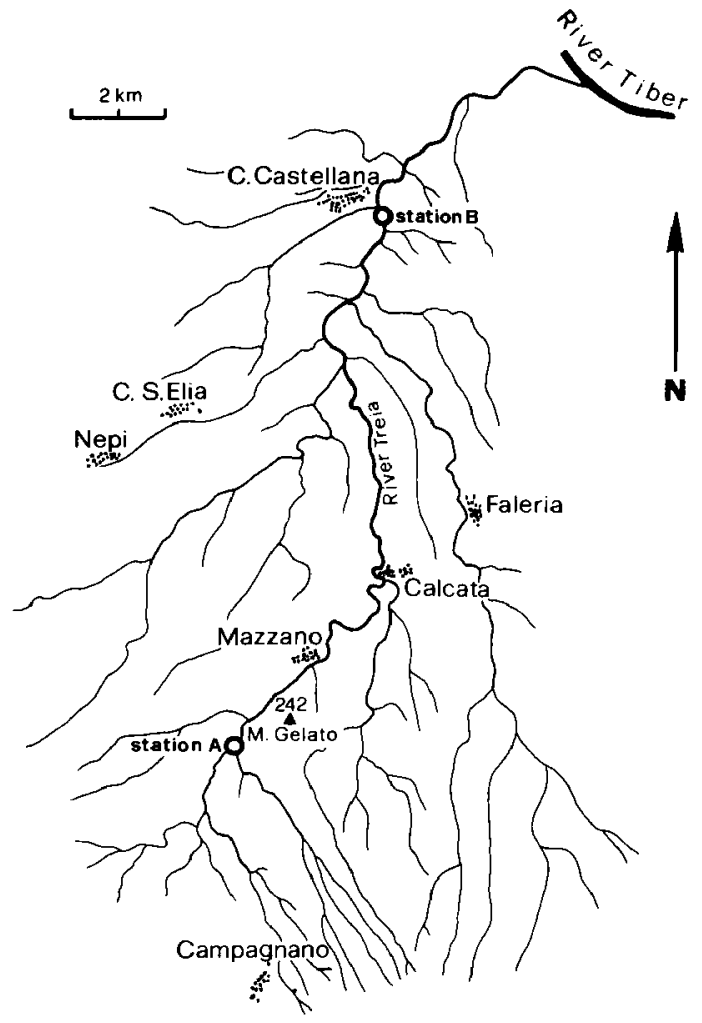

Fig. 1. Map of the River Treia showing the two sampling stations.

(10), were collected during the study (Tables I and II). The most abundant groups were Oligochaeta, Gammaridae, Diptera Chironomidae and Ephemeroptera (fig. 3).

In both stations, total collectors (almost all collector-gatherers) and shredders were the dominant groups (Table III), together reaching an annual average percentage of $87.7 \%$ in $A$ and $89.2 \%$ in
B. A positive correlation between taxonomic and feeding group diversities $(r=0.92, p<0.001)$ and between taxonomic and feeding group evenness was found. Since the two indices displayed a very similar picture, only the evenness values are graphically reported here (fig. 4). Figures 5 and 6 illustrate a significant positive correlation between predator densities and both total collector (particularly collector-gatherers) and shredder densities. 


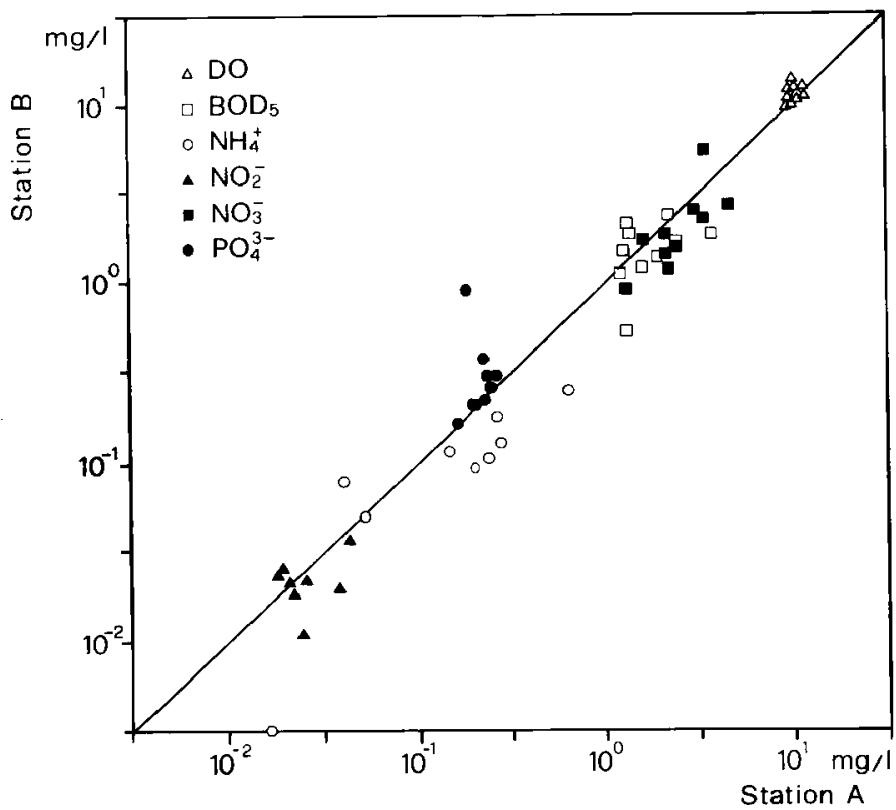

Fig. 2. Chemical comparison of the two stations (data from Decernber 1977 to October 1978). Median line indicates equal concentrations of chemical parameters. Points above the line indicate higher concentrations at Station $B$ and points below the line indicate higher concentrations at Station $\mathrm{A}$.

\subsection{Differences between the two stations}

A similar number of taxa (46 in $A$ and 40 in B) was collected during the study, 27 of which being present in both stations (Tables I and II). Only Oligochaeta, Hirudinea and Chironomidae resulted significantly more abundant in station $\mathrm{A}$ than in $\mathrm{B}$ (Table IV). Considering the most abundant species in both stations, Psammoryctides barbatus, Limnodrilus hoffmeisteri, Dina lineata, Caenis sp. and Polypedilum scalaenum (syn. breviantennatum) occurred in higher densities in A than in B. PSc arrangement of taxonomic data during the sampling period (fig. 7) revealed a quite clear separation of the two stations and a strong similarity ( $>50 \%$ ) only within station A samples.
The absolute numbers of total collectors, collector-gatherers and predators were higher in A than in $\mathrm{B}$ (Table IV), but no significant differences were recorded in the proportions of all the feeding categories. Compared with the PSc results using taxa abundance, PSc dendrogram based on the relative abundance of the feeding groups shows a higher similarity between the stations (fig. 8). Although taxonomic and feeding group diversities and evenness showed a greater numerical variation in station $\mathrm{B}$ than in $\mathrm{A}$, no significant differences were noted in the values of these indices (Table IV). The higher variability in most of the community parameters at station B can be partly ascribed to two factors : a) the higher numerical presence of opportunistic taxa, such as Naididae, which rapidly increase 
Date Jun, Fet. apr. Jusp. Aug. Oct.

tix

Q IGOCHATA

Pristing! astonlsels Bourne ([6)

Prjuting ip. iCg

Nijs coweunis Piguet (CG)

n. birtal initleri (CG)

H. elinguis Nüler (C6)

oero digitut (holl ter) (C6)

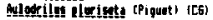

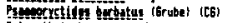

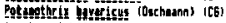

ieature tubifleids with hair chatas (C6)

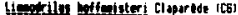

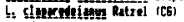

L. udeteginge Clapurto (CG)

Lubriculidae (CG)

HIRUDIMEA

binn lingets (Hijleri (P)

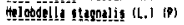

AMPHIPQRA

Echingodiwarvs bungens (Edm.) (5H)

[S0P0DA

Prodsellus cotalis Dollf, (SW)

PLECOPTERA (SN, P)

EPHENEROP TERA

Cyenis luctuoss (lurkistor) (C5, 56)

Crenis so. ICG, 5

Eqhegere!! ignite !Padal IC6, SCI

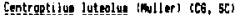

Habrophlegia tuse icurtis) (CG, SC)

ODONATA

Gaigeterys sp. $\{P \mid$

IATCHOPTERA

Hydrossychidat (CF, P)

CQLEOPTEPA

Elaj dae $165,5[$ )

OTPTERA Chiponotids

Orthoclatius sp./spp, (CS)

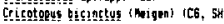

Rheocricotopess effusus-diger iCG, 5H, P)

Prodianega olivaced Heigen (CE)

Pentaneurini $\mid P i$

Pracl pdies $(p . / \mathrm{spp}$. (p)

Mactogelopis $50,15 \mathrm{gs}$, (P)

Pyestratanyeus varitz Fabricius (P)

nicrossptro $30 . / \mathrm{spg}$. (C6)

[enytirass ip.ispp. (C6, CF)

Cladat apytursys sp./spp. (CS, CF)

ineotanytertis sp./spp. (CF)

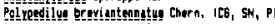

Paratendieas sp./spp. (CE)

Phateposectra $5 \mathrm{p}, / \mathrm{spp}$, ([E, SC)

Crytpehirongess sp./spp. (P)

chirongeyt thumi gr. (CE, 5H)

DIFIERA Ceratopogonidae (ES, P)

GASTROPECA

Lrended sp, 15C, sal

JIUALVIA

Pisidiug spo. |EF|

$\begin{array}{llllll}0 & 0 & 0 & 0 & 2 & 0 \\ 0 & 0 & 1 & 0 & 1 & 0 \\ 0 & 1 & 0 & 0 & 0 & 0 \\ 0 & 0 & 2 & 0 & 0 & 0 \\ 0 & 0 & 3 & 2 & 0 & 0 \\ 0 & 0 & 1 & 0 & 0 & 0 \\ 2 & 0 & 0 & 0 & 0 & 2 \\ 3 & 2 & 2 & 2 & 2 & 1 \\ 0 & 0 & 2 & 0 & 0 & 0 \\ 3 & 2 & 2 & 2 & 2 & 0 \\ 1 & 3 & 3 & 1 & 1 & 3 \\ 2 & 0 & 0 & 0 & 0 & 0 \\ 0 & 0 & 0 & 0 & 2 & 0 \\ 0 & 1 & 2 & 0 & 1 & 1\end{array}$

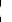
i

1




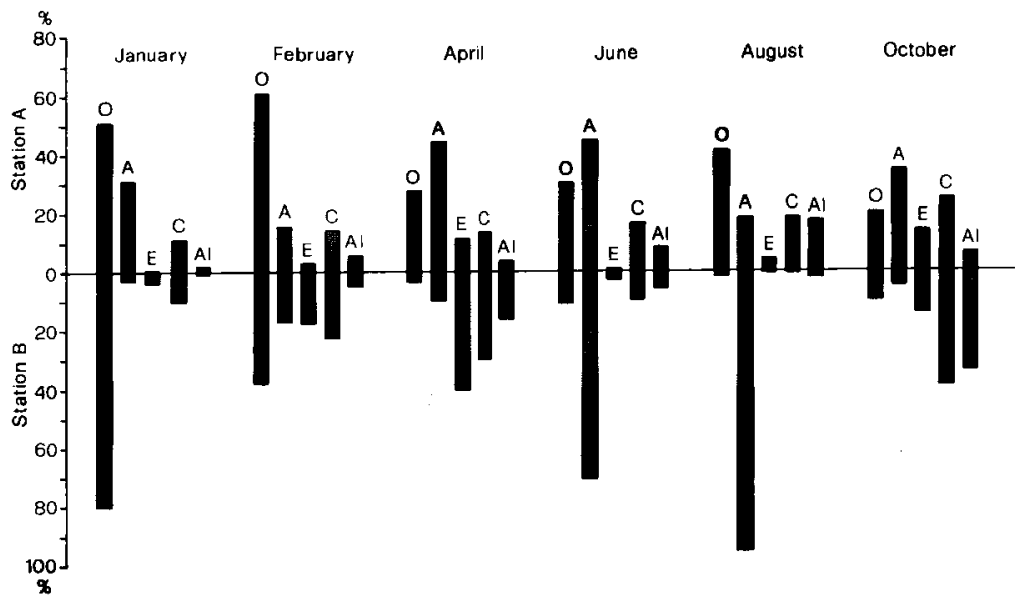

Fig. 3. Seasonal relative abundances of the macroinvertebrate groups at the two stations during 1978. $\mathrm{O}=$ Oligochaeta, $\mathrm{A}=$ Amphipoda, $\mathrm{E}=$ Ephemeroptera, $\mathrm{C}=$ Chironomidae, $\mathrm{Al}=\mathrm{Alia}$.

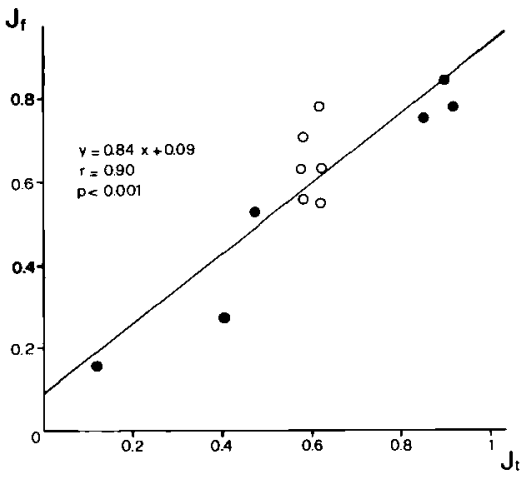

Fig. 4. Linear relationship (two-tailed test) between taxonomic (Jt) and feeding group (Jf) evenness. Circles and dots indicate Station $\mathbf{A}$ and Station $\mathbf{B}$ values, respectively.

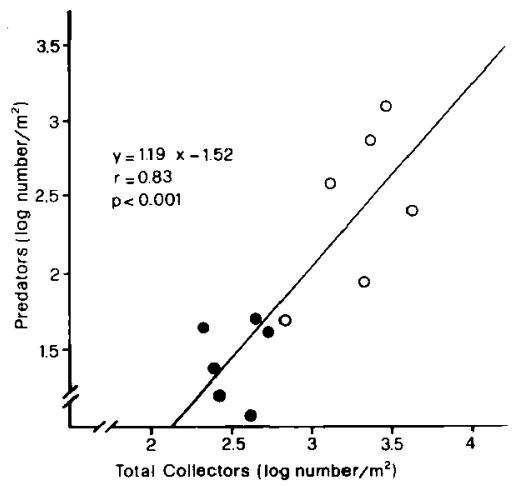

Fig. 5. Linear relationship (two-tailed test) between Tot: Collector and Predator densities. Circles and dots as in Fig. 4. 


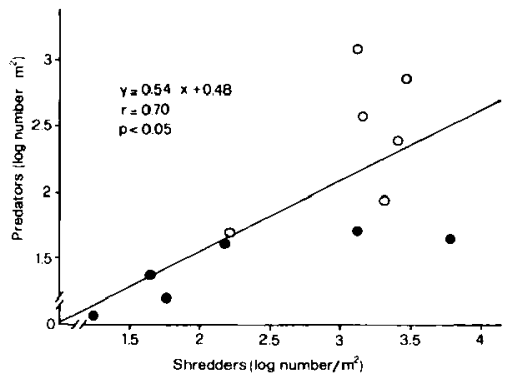

Fig. 6. Linear relationship (two-tailed test) between Shredder and Predator densities. Circles and dots as in Fig. 4.

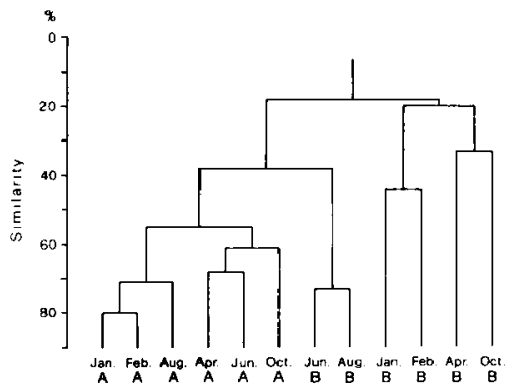

Fig. 7. Similarity (PSc) among stations (A and B) and dates, based on macroinvertebrate taxa abundances.

Table III. Seasonal and annual mean (a.m.) values of functional feeding group percentages at the two stations. Feeding categories as in Tables I and II ; TC $=$ Total Collectors.

$\begin{array}{rlrrrrrrr}\text { Stution A } & \text { CF } & 1.8 & 3.2 & 1.1 & 0.3 & 0.5 & 2.5 & 1.5 \\ & \text { P } & 3.5 & 5.5 & 1.9 & 12.0 & 21.1 & 11.2 & 9.3 \\ & \text { SH } & 36.1 & 18.5 & 45.2 & 18.6 & 23.0 & 12.6 & 35.7 \\ & \text { SC } & 0.4 & 1.3 & 6.3 & 0.4 & 2.9 & 7.3 & 3.1 \\ & & & & & & & & \\ & & & & & & & & \\ & \text { TC } & 91.4 & 69.5 & 62.1 & 24.2 & 3.3 & 69.0 & 53.2 \\ \text { Station 8 } & \text { C6 } & 90.5 & 57.3 & 47.9 & 21.3 & 2.7 & 57.9 & 46.3 \\ & \text { CF } & 0.9 & 12.2 & 14.2 & 2.9 & 0.6 & 11.1 & 7.0 \\ & \text { P } & 2.6 & 5.6 & 3.8 & 2.8 & 0.7 & 6.8 & 3.7 \\ & \text { SH } & 3.8 & 19.2 & 13.9 & 71.3 & 95.2 & 12.8 & 36.0 \\ & \text { SC } & 2.2 & 5.7 & 20.2 & 1.7 & 0.8 & 11.4 & 7.0\end{array}$

Table IV. Significance of Wilcoxon-test comparisons for absolute numbers of the most aburidant taxa and of the functional feeding groups, and for community parameters bet ween the two stations (in all comparisons Station A > Station B). n.s. = not significant. Only taxa present in both stations are considered.

Total fauna
Oligochaeta
Hirudined
Epheaeropter a
Chironosidae
Ceratopogonidae

n.s. $p<0.05$ $0<0.05$

ก.5. $0<0.05$ n.s.

N. elinguis n.5.

P. barbatus $\quad 0<0.05$

L. hoff́neisteri $\quad p<0.05$

D. lineate

E. Pungens

$p<0.05$

n. 5.

Caenis sp.

$p<0.05$

C. luctuosa $\quad$ n.5.

E. ignita n.5.

Orthocladius sp./spp. n.s.

Cryetochironogus sp./spp. n.s.

Paratendipes sp./spp. n.s.

P. breviantennatute $\quad 0<0.05$

Pisidiue spp. n.s.

Total Collector $\quad 0<0.05$

Collector-gatherer $\quad 0<0.05$

Collector-filterers n.s.

Shredders n.s.

Scrapers n.s.

Predators $\quad p<0.05$

Nuber of taxa n.s.

Taxonosic diversity n.s.

Taxonosic evenness n.s.

Functional feeding group diversity n.s.

functional feeding group evenness n.s.

in abundance over a relatively short period of time (Hughes 1975, Rodriguez 1984), and b) the postreproductive high percentages of Echinogammarus pungens.

PCA analysis using taxa abundances showed no consistent pattern in the spatial distribution and 


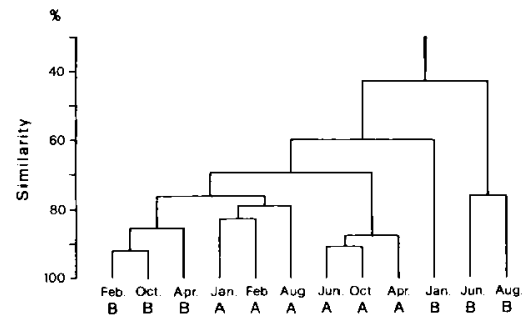

Fig. 8. Similarity (PSc) among stations (A and B) and dates, based on functional feeding group abundances.

seasonal variations among the samples, so that the graphic is not reported in this paper. Conversely, PCA based on functional feeding group densities (fig.9 and Table V) illustrates a clear separation of station A from station B. Predators, collectorgatherers and shredders result ed the major variables of PCl, while collector-filterers and scrapers influenced the definition of $\mathrm{PC} 2$. Moreover, $\mathrm{PC} 1$ scores were negatively correlated with $\mathrm{DO}$ values and positively with $\mathrm{NO} 3$ and $\mathrm{NO} 2$ contents (Table V). These results suggest that the axis is interpretable as a gradient of water quality and the abundance of predators, collector-gatherers and shredders were favoured by little increases of organic pollution.

\section{Discussion and conclusion}

The two stations supported communities with partly different composition and absolute densities of some taxa and of functional feeding groups. However, they also showed similar annual average diversity and evenness values, and proportions of functional feeding groups. This partial similarity was probably due to their similar substrate and water quality.

As expected, the community in both stations was mainly composed of typical main groups (Oligochaeta, Amphipoda, some Ephemeroptera and Diptera Chironomidae) generally inhabiting soft bottom with a moderate current flow (Hynes 1970, Learner et al. 1971, Ward 1975, Barton \& Cock 1979, Wielgosz 1979, Whitman \& Clark 1984, Corkum 1989). Conversely, Plecoptera, Trichoptera, and rheophilous Ephemeroptera were almost completely
Table V. Factor loadings of the first two principal components from ordination of functional feeding groups. $r=$ coefficient of correlation between principal component scores and environmental parameters. Level of significance :- not significant, ${ }^{*} \mathrm{p}<0.05, * \mathrm{p}<0.01$.

Principal Cooponents

\begin{tabular}{|c|c|c|}
\hline Factors & 1 & 2 \\
\hline Eigenyalue & 2,78 & 1.14 \\
\hline Variance account for $(z)$ & 55.70 & 22.90 \\
\hline
\end{tabular}

Voriables

0.94

Collector-gatherers

0.92

Shredders

0.71

Collector-filterers

0.87

Scrapers

0.78

Coefficient of correlation ( $r$ )

$\begin{array}{lcc}D 0 & -0.604 & - \\ B 0 D & - & - \\ N-N 03 & 0.764 t & - \\ N-N 02 & 0.584 & - \\ N-N H 4 & - & - \\ P-P 04 & - & -\end{array}$

absent from the samples. Relationships between some macroinvertebrate species and/or genera and sediment composition have been already observed in rivers by several authors. Tolkamp (1982) reported Polypedilum breviantennatum and Gammarus preferring sandy substrate. Rae (1985) also found Paratendipes as a characteristic chironomid of coarse sand, and McCulloch (1986) noted that Limnodrilus, Polypedilum, Paratendipes and Caenis were mainly restricted to sandy substrates. Finally, Edmunds (1984) considered Caenis typical of depositional habitat. All these observations are in agreement with the present data about some of the most abundant and diffuse taxa found in the River Treia. 


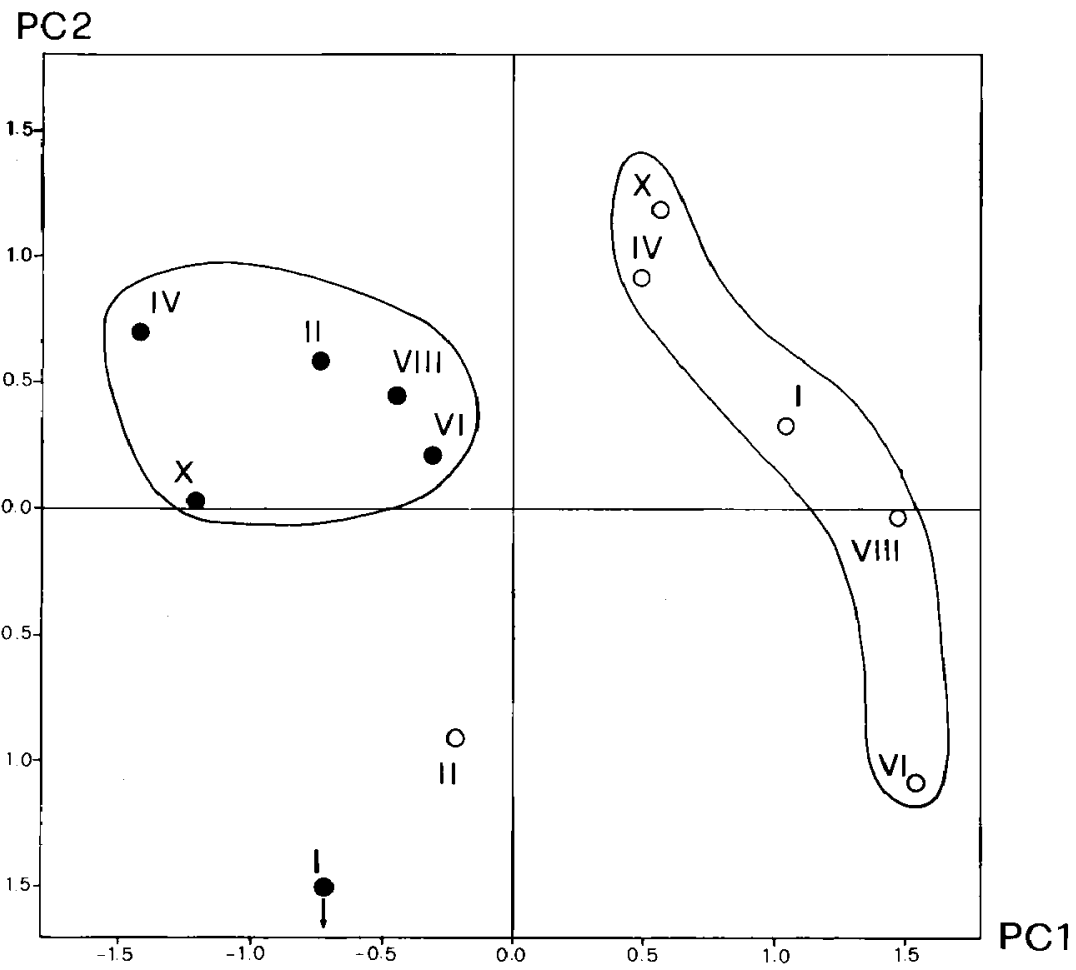

Fig. 9. Plot of factors 1 and 2 of the PCA analysis. Circles and dots indicate Station A and Station B samples, respectively. Roman numbers indicate sampling months.

The dominance of collectors and shredders in both stations is indicative of a rich quantity of fine particulate organic matter (FPOM) and coarse particulate organic matter (CPOM). These results agree with the observations of Rabeni \& Minshall (1977), who explained the preference of detritivore macroinvertebrates for sandy substrate because it served as a better detritus food-collecting device than did the roarser bottom. Functionally, shredders are consi- dered important for processing CPOM into FPOM, favouring the availability of food for collectors (Short \& Maslin 1977). Moreover, the direct relationships between taxonomic and trophic diversities and between taxonomic and trophic evenness indicate that an increase in the two structural parameters of the community induces also an increase in specific feeding types and a more equitable distribution of individuals among them, suggesting a 
quite good partitioning of food resources among the taxa. Finally, the trophic relationship between predators and their potential preys (i.e. collectors and shredders) found in the River Treia was also recorded in other lotic environments with a different (or mixed) substrate composition, and different chemical features of the water (Fahy 1975, Hawkins \& Sedell 1981, Hildrew et al. 1984, Bunn 1986, Barmuta 1988).

With respect to water quality, the macroinvertebrate fauna comprised a relevant proportion of Gammaridae and, to a lesser extent, of Ephemeroptera, i.e. groups that are notoriously sensitive to deoxygenation (cf. Hynes 1960, Hawkes 1979), in our case indicating the absence of heavy organic pollution in both stations. In particular, Echinogammarus pungens is usually considered an oligosaprobic-ßmesosaprobic element (Zelinka \& Marvan 1961, Sládecek 1973) which can tolerate a mild organic pollution (Watton \& Hawkes 1984). According to Goodnight \& Withney (1961), also the percentages of Oligochaeta on the total macroinvertebrates, not exceeding $80 \%$, can exclude forms of gross organic pollution and suggest a moderate state of organic enrichment. At the same time, the large proportion of Oligochaeta recorded in some sampling dates indicates an abundant presence of organic matter in both stations. According to chemical data (cf. values of $\mathrm{N}$ compounds) and PCA results, this fact seems to be more accentuated at station $A$, which also showed higher absolute numbers of detritivores (collector-gatherers and shredders) and Tubificidae, especially $L$. hoffmeisteri, a polysaprobic species which tolerates organic pollution (Brinkhurst 1966, Sládec̄ek 1973, Uzunov et al. 1988). Moreover, the other more abundant taxa, such as $N$. elinguis, P. barbatus, H. stagnalis, Caenis, Baetis, Orthocladius, Polypedilum and Paratendipes, are all $\beta-\alpha$ mesosaprobic elements, characterizing intermediate conditions from clean to severely polluted waters (Sládeček 1973, Hynes 1970, Lafont 1977, Watton \& Hawkes 1984, Hellawell 1986, Uzunov et al. 1988). Overall, the results of the analysis on the composition and structure of the benthic fauna of the River Treia are in agreement with the chemical diagnosis of the water. Therefore, as observed in studies on hard bottom macroinvertebrates, also the fauna associated with fine sediments seems to be suitable for detecting the water quality of rivers, especially in cases of moderate organic pollution. In order to test the general validity of these observations, further studies on rivers with different degrees of organic enrichment are required.

In conclusion our results suggest that more emphasis should be placed on macroinvertebrates living in this type of substrate in future stream researches, also considering that, despite its physical instability due to floods, this habitat can be very common and sometimes dominant in several lotic environments (i.e. lowland rivers, regulated rivers, channels). According to Logan \& Brooker (1983) and Lenat (1988), studies of biological surveillance could be carried out on the fauna of more diverse type of habitats, including soft bottoms, to obtain comparable data of use in providing a more reliable and comprehensive diagnosis of the biological water quality in rivers.

\section{Acknowledgements}

We wish to thank Dr L. Ferrero for organizing the general research on the River Treia and the following people for identification of some macroinvertebrate groups : Dr $\mathrm{F}$. Baldari $(P$. coxalis), Dr C. Belfiore (Ephemeroptera), Prof A. Minelli (Hirudinea), Prof B. Rossaro (Chironomidae : Orthocladiinae), and Prof S. Ruffo (E. pungens). Thanks are also due to Dr A. Borgioli for providing chemical data and the ACEA for permission to publish them, Dr C. Tamorri for his valuable help with compuring, Dr N. Falchi for drawing the figures and Dr M. Seminara for typing the manuscript. Finally, two anonymous referees kindly provided comments on the manuscript.

\section{References}

Alvarez (W.). 1972. - The Treia Valley North of Rome : volcanic stratigraphy, topographic evolution, and geological influences on human settlement. Geol. Rom.; 11 : 153-176.

Barmuta (L.A.). 1988. - Benthic organic matter and macroinvertebrate functional feeding groups in a forested upland stream in temperate Victoria. Verh. Internat. Verein. Limnol., 23 : 1394-1398.

Barton (D.R.) \& Lock (M.A.). 1979. - Numerical abundance and biomass of Bacteria, Algae and macrobenthos of a large northern river, the Athabasca. Int. Revue ges. Hydrobiol., 64 : 345-359.

Blasi (C.), Abbate (G.) \& Fascetti (S.) \& Michetti (L.). 1981. $L a$ vegetazione del bacino del $F$. Treia. CNR, AQ/1/237 : $33 \mathrm{p}$.

Brinkhurst (R.O.). 1966. - The Tubificidae (Oligochaeta) of polluted waters. Verh. Internat. Verein.'Limnol., 16 : 854-859.

Bunn (S.E.). 1986. - Spatial and temporal variation in the macroinvertebrate fauna of streams of the northern jarrah forest, Western Australia : functional organization. Freshwat. Biol., $16: 621-632$.

Cook (S.E.H.). 1976. - Quest for an index of community structure sensitive to water pollution. Environ. Pollut., I! 269-288. 
Corkum (L.D.). 1989. - Patterns of benthic invert ebrate assemblages in rivers of northwestern North America. Freshwat. Biol., 21 : $191-205$.

Cummins (K.W.). 1962. - An evaluation of some techniques for the collection and analysis of benthic samples with special emphasis on lotic waters. Amer. Midl. Nat., $67: 477-504$.

Cummins (K.W.) \& Wilzbach (M.A.). 1985 . - Field procedures for analysis of functional feeding groups of stream invertebrates. Appalachian Environmental Laboratory, Univ. Maryland, Frostburg. Contr. $N^{\circ} 1611: 18 \mathrm{p}$.

Doledec (S.). 1987. - Etude des peuplements de macroinvertébrés benthiques de l'Ardèche dans son cours inférieur. Arch. Hydrobiol., $109: 541-565$.

Eason (G.), Coles (C.W.) \& Getinby (G.). 1980. - Mathematics and statistics for the biosciences. Chichester, Ellis Horwood Ltd. : $578 \mathrm{p}$.

Edmunds (G.F.). 1984. - Ephemeroptera. In : Merritt (R.W.) \& Cummins (K.W.), eds., An introduction to the aquatic insects of North America. Kendall/Hunt Publishing Company, Dubuque, lowa : 94-125.

Fahy (E.). 1975. - Quantitative aspects of the distribution of invertebrates in the benthos of a small stream system in western Ireland, Freshwat. Biol., 5 : 167-182.

Goldman (C.R.) \& Horne (A.J.). 1983. - Limnology. Mc Graw-Hill Internat. Book Company : $464 \mathrm{p}$.

Goodnight (C.J.) \& Whitley (L.S.). 1961. - Oligochaetes as indicators of pollution. Proc. 15th Indust. Waste Conf., Pur. due Univ. Eng. Ext. Ser., 106 : 139-142.

Hawkes (H.A.). 1979. - Invertebrates as indicators of water quality. In : Evison (J.A.), ed., Biological indicators of water quality. J. Wiley and Sons, Chichester, New York, Toronto : $2 / 1-2 / 45$

Hawkins (C.P.) \& Sedell (J.R.). 1981. - Longitudinal and seasonal changes in functional organization of macroinvertebrate communities in four Oregon streams. Ecology, $62: 387-397$.

Hellawell (J.M.). 1978. - Biological surveillance of rivers. Waters Research Centre, Stevenage, England : 332 p.

Hellawell (J.M.). 1986. - Biologicat indicators of freshwater pollution and environmental management. Pollution monitoring series. Elsevier Applied Science Publishers, London, New York : $546 \mathrm{p}$.

Hildrew (A.G.), Townsend (C.R.) \& Francis (J.). 1984. Community structure in some southern English streams : the influence of species interactions. Freshwat. Biol., $14: 297-310$.

Hughes (B.D.). 1975. - A study of a polluted river. Unpublished D. thesis, University of Wales.

Hynes (H.B.N.). 1960. - The biology of polluted waters. Liverpool Univ, Press, Liverpool, England. : 202 p.

Hynes (H.B.N.). 1970. - The ecology of running waters. Toronto Univ. Press, Toronto : 555 p.

Klein (L.). 1962. - River pollution. 2. Causes and effects, Butterworths, London : $456 \mathrm{p}$.

Lafont (M.). 1977. - Les Oligochètes d'un cours d'eau montagnard pollué : le Bief Rouge. Annls Limnol., 13 : 157-167.

Leclercq (L.) \& Maquet (B.). 1987. - Deux nouveaux indices chimique et diatomique de qualité d'eau courante. Application au Samson et d̀ ses affluents. Comparaison avec d'au. tres indices chimiques, biocénotiques et diatomiques. Inst. Roy. Sci. Nat. Belgique, Document de travail, $3: 113 \mathrm{p}$.
Learner (M.A.), Williams (R.), Harcup (M.) \& Hughes (B.D.). 1971. - A survey of the macro-fauna of the River Cynon, a polluted tributary of the River Taff (South Wales). Freshwat. Biol., 1 : 339-367.

Lenat (D.R.). 1988. - Water quality assessment of streams using a qualitative collection method for benthic macroinvertebrates. J. N. Am. Benthol. Soc, $7: 222-233$.

Logan (P.) \& Brooker (M.P.). 1983. - The macroinvertebrate faunas of riffles and pools. Wat. Res., $17: 263-270$.

McCulloch (D.L.). 1986. - Benthic macroinvertebrates distributions in the riffle-pool communities of two east Texas streams. Hydrobiologia, $135: 61-70$.

Merritt (R.W.) \& Cummins (K.W.). 1984. - An introduction to the aquatic insects of North America. Kendall/Hunt, Dubuque, Iowa, USA : $722 \mathrm{p}$.

Nisbet (M.) \& Verneaux (J.). 1970. - Composantes chimiques des eaux courantes. Discussion et proposition de classes en tant que bases d'interprétation des analyses chimiques. Annts Limnol, 6 : 161-190.

Pielou (E.C.). 1969. - An introduction to mathematical ecology. J. Wiley, New York : 286 p.

Rabeni (C.F.) \& Minshall (G.W.). 1977. - Factors affecting microdistribution of stream benthic insects. Oikos, $29: 33-43$.

Rae (J.G.). 1985. - A multivariate study of resource partitioning in soft bottom lotic Chironomidae. Hydrobiologia, 126 : 275-285.

Rodriguez (P.). 1984, - Los Oligoquetos acuaticos del Rio Nervion (Vizcaya, España) : resultados faunisticos generales. Limnética, I : 169-178.

Roeding (C.E.) \& Smock (L.A.). 1989. - Ecology of macroinvertebrate shredders in a low-gadient sandy-bottomed stream. J. N. Am. Benthol. Soc., 8: 149-161.

Schmitz (W.), Buck (H.) \& Vobis (H.). 1979. - Biological water assessment methods. In : Ghetti (P.F.), ed., Biological water assessment methods. Torrente Parma. Torrente Stirone and Fiume Po. 3rd Technical Seminar, Parma, October 1978. Comm. Europ. Comm., 1 : 385-415.

Short (R.A.) \& Maslin (P.E.). 1977. - Processing of leaf litter by a stream detritivore : effect on nutrient availability to collectors. Ecology, $58: 935-938$.

Sládecek (V.). 1973. - System of water analysis from the biological point of view. Arch. Hydrobiol/Ergebn. Limnol., 7 : 1-218.

Sneath (P.H.A.) \& Sokal (R.R.). 1973. -- Numerical taxonomy. Freeman and Co., San Franciso, California : 573 p.

Tolkamp (H.H.). 1982. - Microdistribution of macroinvertebrates in lowland streams. Hydrobiol. Bwhl, $16: 133-148$.

Tümpling (W.). 1969. - Suggested classification of water quality based on biological characteristics. Advances in water pollution research. Proc. 4th Int. Conf. Wat. Poll. Res. Prague, Jenkins (S.H.), ed., Pergamon Press : 279-286.

Uzunov (J.), Kosel (V.) \& Sládecék (V.). 1988. - Indicator value of freshwater Oligochaeta. Acta hydrochim. hydrobiol., 16 : 173-186.

Ward (J.V.). 1975. - Bottom fauna-substrate relationships in a Northern Colorado trout stream : 1945 and 1974. Ecology, $56: 1429-1434$. 
Watton (A.J.) \& Hawkes (H.A.). 1984. - The performance of an invertebrate colonisation sampler (S. Auf. U.) in biological surveillance of lowland rivers. In : Pascoe (D.) \& Edwards (R.W.), eds., Freshwater biological monitoring. Pergamon Press, Oxford : 15-24.

Whitman (R.) \& Clark (W.J.). 1984. - Ecological studies of the sand-dwelling community of an East Texas stream. Freshwat. Invertebr. Biol., 3 : 59-79.

Whittaker (R.H.) \& Fairbanks (C.W.). 1958. - A study of plankton and copepod communities in the Columbia Basin, southeastern Washington. Ecology, 39 : 46-65.
Wielgosz (S.). 1979. - The structure of zoobenthos communities of a fine-grained substrate of the River Lyna. Acta Hydrobiol, $21: 19-35$.

Williams (W.T.), Lance (G.N.), Webb (L.J.), Tracey (J.G.) \& Dale (M.B.). 1969. - Studies in the numerical analysis of complex rain-forest communities. III. The analysis of successional data. J. Ecol, $57: 515-535$.

Zelinka (M.) \& Marvan (P.). 1961. - Zur Präzisierung der biologischen Klassifikation der Reinheit fließender Gewässer. Arch. Hydrobiol, 57 : 389-407. 